\title{
Attitudes of Key Professionals towards People with Intellectual Disabilities and their Inclusion in Society: A Qualitative study in an Indonesian Context
}

\author{
Restu Tri Handoyo, Afia Ali, Katrina Scior, and Angela Hassiotis \\ University College London
}

\begin{abstract}
Author Note
Departmental affiliation

Restu Tri Handoyo, Division of Psychiatry, University College London; Afia Ali, Division of Psychiatry, University College London; Katrina Scior, Division of Psychology and Language Science, University College London; Angela Hassiotis, Division of Psychiatry, University College London.
\end{abstract}

Corresponding author

Correspondence concerning this article should be addressed to Restu Tri Handoyo, Division of Psychiatry, University College London, $6^{\text {th }}$ Floor Maple House, 149 Tottenham Court Road, London W1T 7NF, UK. Email: restu.handoyo.15@ucl.ac.uk

Running Title: Professionals' attitudes towards ID in Indonesia 


\begin{abstract}
This study aimed to explore key professionals' attitudes towards people with intellectual disability (ID) and inclusion of said people in the community. Eighteen participants from three professional groups, comprising health practitioner (medical doctors, psychologists), mainstream/special education teachers, and religious leaders (Islam, Catholicism, Protestantism, Hindu, and Buddhist) were recruited. Semi-structured interviews, aided by two vignettes depicting mild and severe ID, were conducted. Thematic analysis was used to analyse the data. Seven themes were identified exploring perceived causes; use of terminology; attitudes towards people with ID; attitudes towards inclusion, religion and ID; family-centric support, and challenges faced by people with ID in a wider context. Perceived capabilities of persons with ID were found to influence attitudes towards people with ID and their inclusion. Availability and accessibility of good quality services were also found to influence attitudes towards the inclusion of people with ID. Cultural factors related to attitudes towards ID are discussed.
\end{abstract}

Keywords: Intellectual disabilities, attitudes, professional, culture, Indonesia 


\section{Introduction}

Intellectual disability (ID) is characterised by significant limitations in both intellectual functioning (e.g. learning, reasoning, problem-solving) and adaptive behaviours (e.g. conceptual, social, and practical skills), with an onset before the age of 18 (American Psychiatric Association, 2013). It is now widely accepted that the functioning and well-being of people with ID is influenced significantly by environmental and social factors that can limit access to opportunities others take for granted, such as valued social roles and fulfilling activities (Werner \& Scior, 2016). A meta-analysis of international population-based studies estimates that ID prevalence averages around $1.04 \%$ with higher rates in low and middleincome countries (Maulik, Mascarenhas, Mathers, Dua, \& Saxena, 2011)

It has been noted that people with ID are among the most stigmatised and excluded in society (Ditchman et al., 2013). Efforts to increase social inclusion of people with ID have taken place in many countries following the ratification of the Convention on the Rights of Persons with Disabilities (CRPD). Alongside efforts to promote positive attitudes towards people with ID through laws and public policies, it is crucial to explore dominant attitudes in society, their formation, and the presence of negative attitudes that hamper the inclusion of people with ID in everyday life (Yazbeck, McVilly, \& Parmenter, 2004). Understanding attitudes prevalent in society is also relevant in achieving social change and evaluating the effectiveness of public policies in the promotion of inclusive approaches to people with ID (Werner \& Scior, 2016). Attitudes towards disabilities are socially constructed and shaped by experience (Tregaskis, 2000). An international study covering countries in Asia, including Indonesia, found significant differences in the degree of inclusion of people with disabilities, which the authors attributed partly to differences in religious beliefs across the countries studied (Berry \& Dalai, 1996). Studies in Cambodia also highlight the role of religion in shaping attitudes towards ID (Carter, 2009; Moreira, 2011). 


\section{Indonesian Context}

Indonesia is an archipelagic country with an estimated population of around 255 million people (Indonesia Statistics, 2015) which comprises of more than 600 ethnic groups (Arifin, Ananta, Wilujeng Wahyu Utami, Budi Handayani, \& Pramono, 2015). Although little data is available on the prevalence of people with ID in Indonesia, the number of people with disabilities is estimated to be $11 \%$ (Indonesia Ministry of Health, 2013). This figure appears to be an underestimate, as the World Health Organization and the World Bank (2011) estimate that disability affects around $15 \%$ of the global population, with a higher prevalence in developing countries. Challenges for collecting accurate data concerning people with disabilities in Indonesia include both families' tendencies to hide members with disabilities (Mujaddid, 2014) as well as the constantly changing definitions of disability (Irwanto; Kasim, Fransiska, Lusli, \& Okta, 2010). Access to services in Indonesia are also lacking; it is reported that only 1 out of 101 people with disabilities has access to services (Riana, 2014). People with disabilities also have limited access to education and employment (Prasetyo, 2014).

Indonesia has joined efforts to ensure the right of people with disabilities and to endorse their inclusion in society by ratifying the CRPD in 2011. However, the implementation of the Convention in Indonesia is not without its challenges. Edwards (2014) highlighted the absence of enforcing systems and presence of old laws which contradict statements made in the CRPD. In addition, public stigma towards people with ID is reported to be prevalent in Indonesian society (Komardjaja, 2005). Considering how attitudes are bound to cultural contexts (Berry \& Dalai, 1996; Carter, 2009; Moreira, 2011; Tregaskis, 2000), it follows that Indonesia is a complex setting for studying attitudes towards people with ID. In addition, religion plays a fundamental role in Indonesian society as it is endorsed by the Five Principles (Pancasila), the national ideology that positions "Belief in one God" as its first principle (Budiyono, 2014). Indonesia recognizes six religions-Islam, Protestantism, Catholicism, Hinduism, Buddhism, 
and Confucianism - and requires every Indonesian to either be a member of one of these religions (Jones, 2005; Woodward, 2011) or affiliate with local indigenous faiths.

The present study was designed to explore the attitudes of key professionals working with people with ID in Indonesian communities. Three groups of professionals were included in this study: health professionals, teachers, and religious leaders. These professional groups were selected because of their essential role in promoting inclusion and providing access to education, treatment and support. The participants are considered as key professionals because they are often the main formal contact in the management of people with ID. Medical doctors and psychologists provide a formal diagnosis of ID and recommendations for treatments. Teachers may identify cases of students with ID in their classrooms, make referrals to health professionals, and to more specialised education—sometimes without a formal diagnosis. In the Indonesian context, religious leaders are sought out by their followers for treatment, including for disabling conditions. It is also important to investigate religious perspectives towards people with ID in an Indonesian context. Participants were recruited from four urban areas in Java, namely Jakarta, Tangerang, Bogor and Bekasi. This study aimed to address the following questions:

1. What attitudes towards people with ID are held by key professionals in Indonesia?

2. What are their attitudes towards inclusion of people with ID in Indonesia?

\section{Methods}

\section{Instrument development}

A semi-structured interview schedule and two vignettes depicting a person with mild ID and a person with severe ID were utilised in this study (see Appendices A and B). The interview guide aims to explore participants' perceptions regarding likely causes of ID, attitudes towards people with ID, and attitudes towards the inclusion of people with ID in society. Attitudes 
towards inclusion were explored in relation to five domains: education, employment, marriage and parenthood, participation in community activities, and living arrangements. The interview guide was developed for the purpose of this study, guided by the literature. For instance, questions about causal belief were based on the suggestion of its influence towards attitude (Scior \& Furnham, 2016) and questions about participation in community activities such as wedding ceremony and religious service were based on finding that people with ID are excluded in such activities (Moreira, 2011). The vignettes were used during the interview to provide a description of people with ID as well as a reference point for participants without any prior contact with people with ID. The vignette depicting mild ID was developed based on Morin, Crocker, Beaulieu-Bergeron, and Caron (2013) work. The instruments were piloted with three members of the key professions: a clinical psychologist, a mainstream education teacher and a Muslim religious leader, and were refined based on their inputs.

\section{Participant selection and recruitment}

The present study was approved by University College London Research Ethics Committee, project ID number $8849 / 001$. In total, 18 participants were interviewed, including five health professionals, five teachers, and eight religious leaders. Convenience sampling was practised, using work and personal contacts of the main investigator (RTH) as well as those of two collaborating service providers. The participants recruited from work/personal contacts were sent an email containing an invitation and information sheet about the study, whilst those recruited via service providers received the invitation and information sheet from their respective organisations. Participants provided written consent and were interviewed at the time and place of their choosing. Four participants chose to be interviewed by phone. Data saturation was examined in twelve transcripts and determined when no further themes were identified in the next three transcripts (Francis et al., 2010). Figure 1 depicts the recruitment process of this study. 


\section{Data collection}

Interviews were conducted in Indonesian and audio recorded. The interviews lasted between 35 and 64 minutes, with an average of 48 minutes. The participants were given a chance to read the two vignettes prior to the interview and to refer to the vignettes anytime during the interview. Transcripts were then translated into English by a translation service, and the translation was reviewed for quality by RTH.

\section{Data analysis}

Data were analysed after the translation to English. We used thematic analysis to identify patterns (themes) within the collected data, following the six steps proposed by Braun and Clarke (2006) namely familiarisation with data, generating initial codes, searching for themes, reviewing themes, defining and naming themes, and producing reports. Initial familiarisation with data was done by reading each interview transcript several times. The qualitative data management programme NVivo 11 was used to generate codes and search for themes. The initial coding structure was made by RTH with input from AA and AH, who met regularly to review and discuss the coding structure and analysis. The coding structure was then independently reviewed by another researcher (RA) to check its reliability; differences were discussed to establish the final structure. Data were analysed together across professional groups, with participants' group membership attached to each citation. 


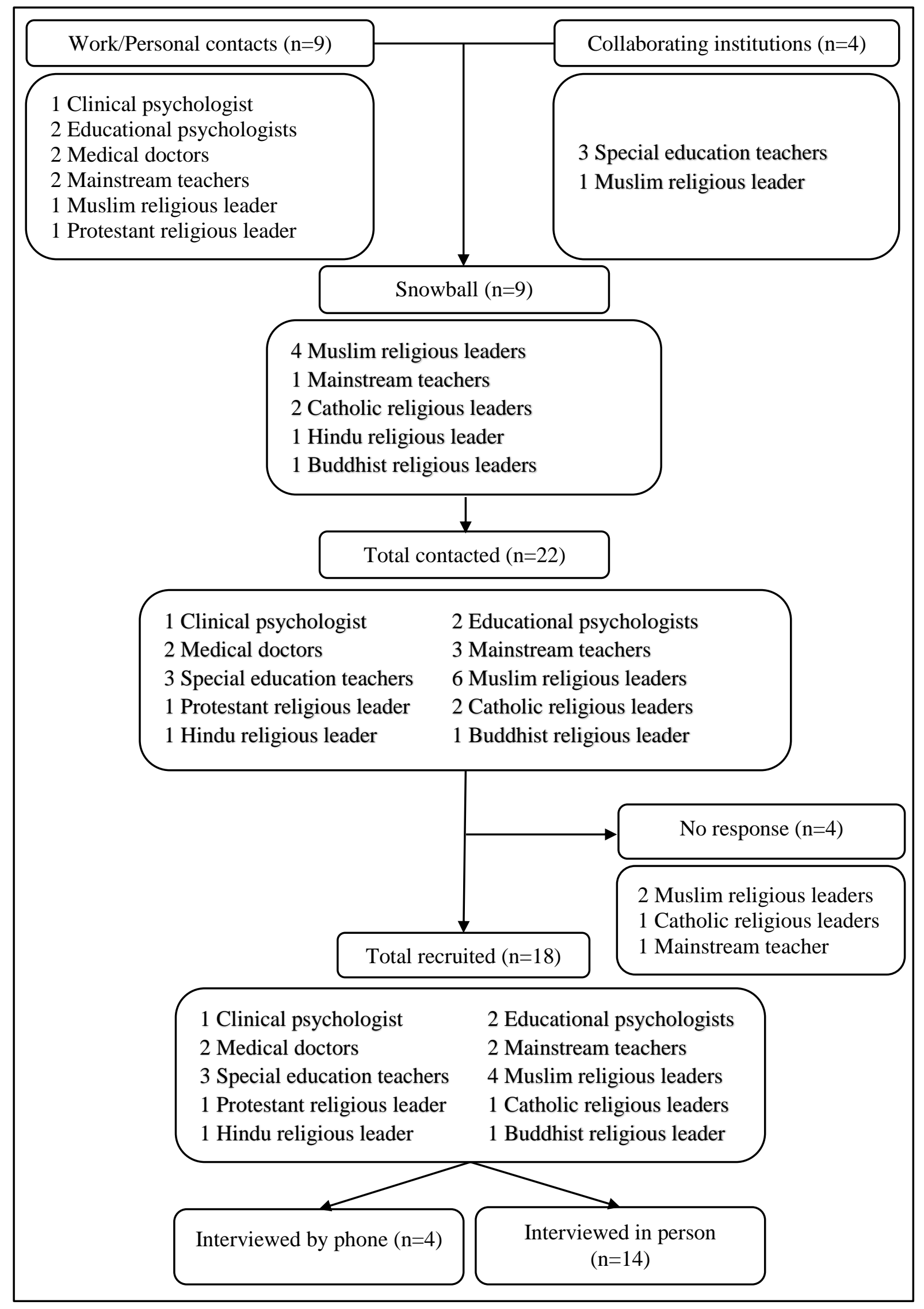

Figure 1. Participant recruitment flow 


\section{Results}

\section{Participant demographics}

The composition and characteristics of the participants are shown in table 1.

Table 1. Characteristics of the participants

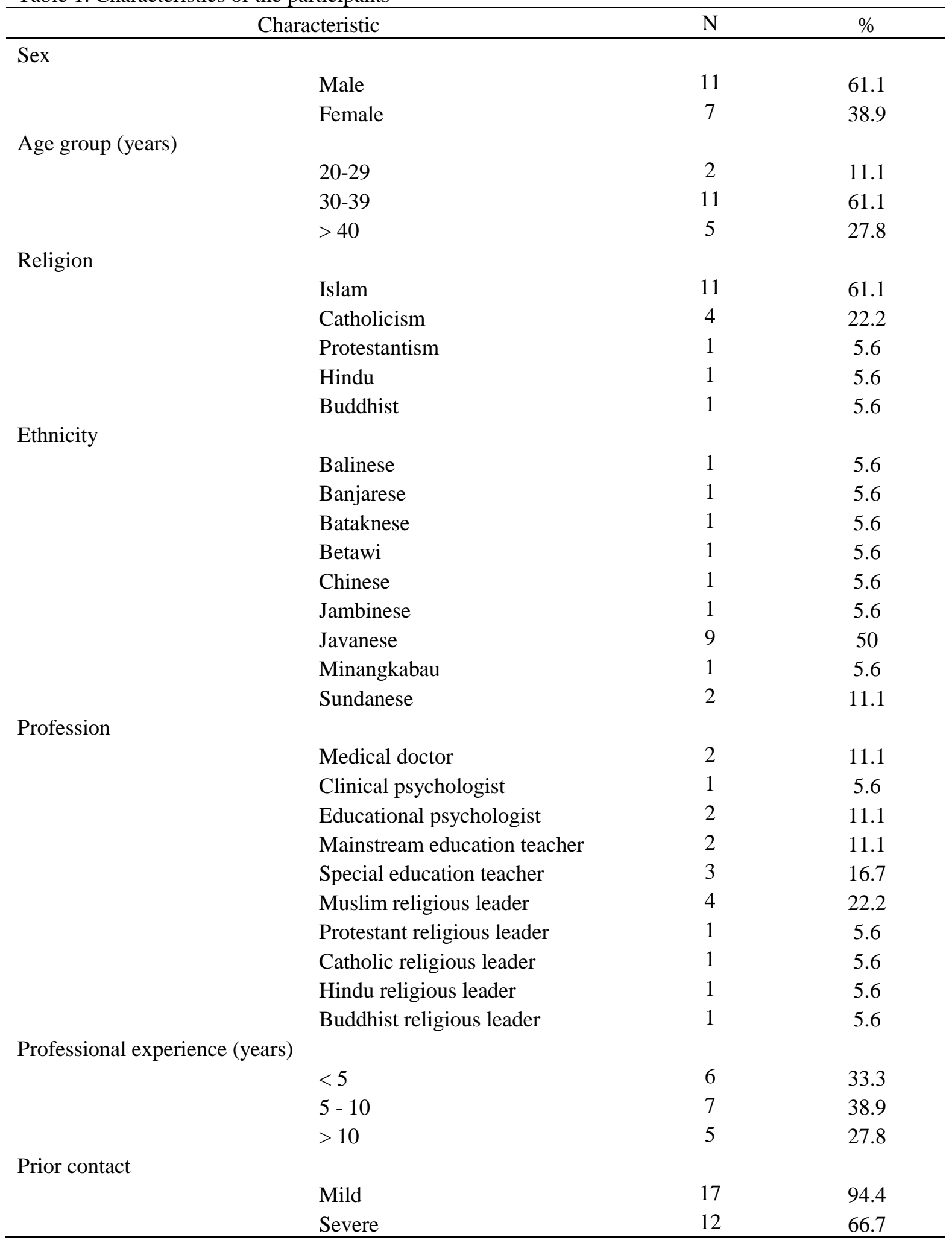




\section{Themes}

Seven themes were identified during analysis: perceived cause of ID, use of terminology, attitudes towards people with ID, attitudes towards inclusion of people with ID, family-centric support, religion and ID, and challenges faced by people with ID in a wider context. Themes reported are limited to those recurring in at least four interviews.

\section{Theme one: Perceived cause of ID}

Causal beliefs regarding ID influence attitudes towards people with it (Carter, 2009; Moreira, 2011; Scior \& Furnham, 2016). Perceived causes of ID among participants were divided into three categories, i.e. medical-related causes, religious-related explanations of causes, and lay explanations of causes. The three most frequently reported medical-related causes were malnutrition, accidents, and hereditary factors. Malnutrition was perceived as happening during the prenatal stage and associated with poverty and maternal malnutrition. Participants discussed accidents, e.g. head injuries during early childhood. Hereditary factors were described in a general way as a characteristic that runs in the family or is inherited from one or both parents.

\footnotetext{
Maybe the parents' economic condition also affects him, and there was malnutrition during pregnancy (P13/teacher mainstream education)
}

Religious causes were mentioned by six participants, mostly from the religious leader's group but also by a clinical psychologist who associated hereditary factors with 'the will of God'.

I tell parents that it is a test from God, which is meant to dignify them... they need to believe that their condition is an ordeal from the creator (P09/religious leader-Islam)

...the child's disability may be the results of his/her deeds from the previous life (P17/ religious leader-Hindu) 
Participants mentioned two causes of ID classified as lay explanations, namely maternal stress during pregnancy and lack of stimulation of the infant/child.

It is a condition that develops before the child was born... perhaps it is because the mother feels stressed during pregnancy (P06/special education teacher)

Lack of stimulation... could also lead to becoming a slow-learner (P03/clinical psychologist)

\section{Theme two: Use of terminology}

The way terminology is used to describe people with ID in society may influence and also reflect attitudes towards them (Scior et al., 2015). Participants stated that the term 'deficiency in thinking' (tuna grahita) is commonly used to refer to people with ID in Indonesia.

This is the first time I heard the term intellectual disability... I have heard about mental retardation, but we usually use the term tuna grahita (P08/Teacher special education)

Alternative terms that overlap with other diagnoses were also used, e.g. 'children with special needs' (anak berkebutuhan khusus), learning difficulty (kesulitan belajar) and 'diffability' (difabel) which refers to the concept of 'differently able'. The term 'educable' (mampu didik) and 'trainable' (mampu latih) were used in education setting.

Rudy (mild ID) can care for himself in eating and dressing; the term for him is educable. Gilang (severe ID) should be trained to care for himself; the term for him is trainable (P08/teacher special education)

Derogatory terms such as 'idiot' and mental handicap (cacat mental) were reported to be used among lay people. Among the derogatory terms used to refer to people with ID, some ('mental disturbance', 'madman') have overlapping meaning with the term used to address people with mental illness, especially psychosis; suggesting a lack of differentiation between mental illness and ID among lay people. 
Unfortunately, they usually use the term of 'mental disturbance' (gangguan jiwa) or 'madman (orang gila) to these people (P11/religious leader-Protestant)

\section{Theme three: Attitudes towards people with ID}

This theme encompasses participants' attitudes towards people with ID. Four sub-themes were identified; see Figure 2.

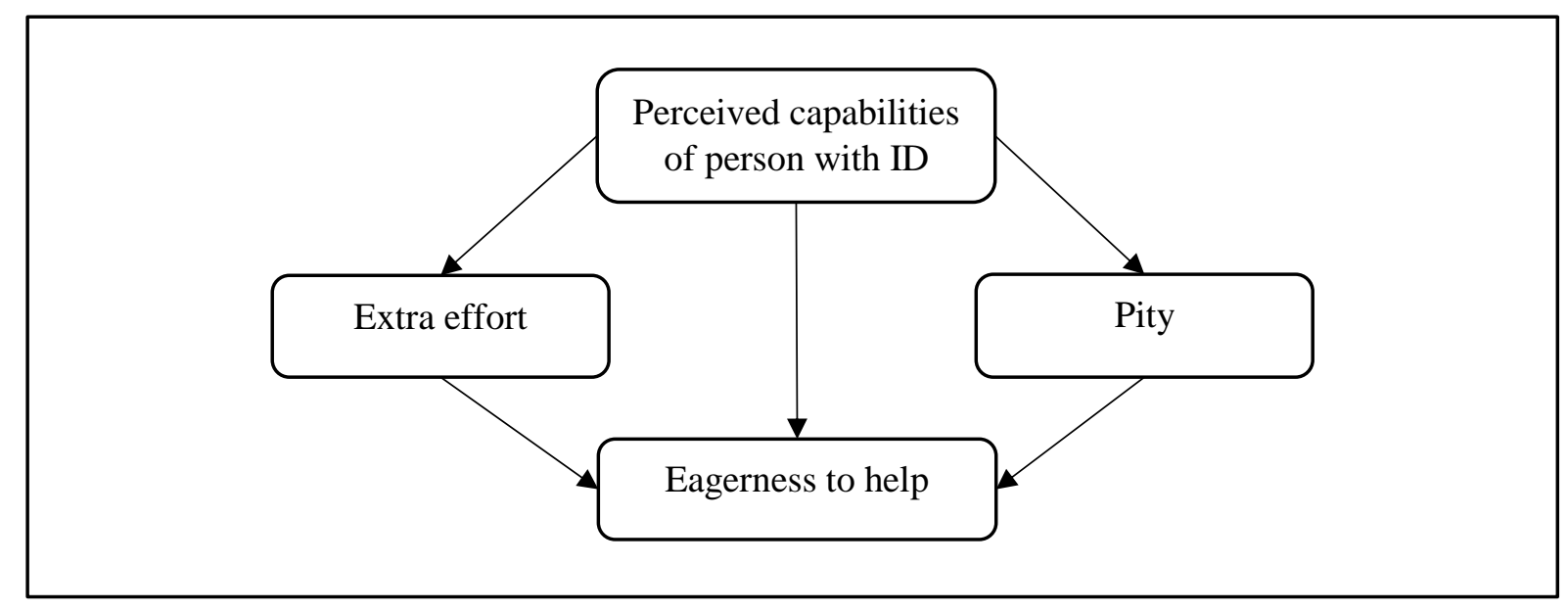

Figure 2. Attitudes towards people with ID

Positively perceived abilities led to positive attitudes towards persons with ID, and as a consequence, people with severe ID received less favourable opinions than counterparts with mild ID.

In his future, Rudy (mild ID) will stay at home, helping his mother with her kiosk at home. He can do various activities, but is limited to his house... Gilang (severe ID) will be stuck at home until he is old. Maybe he will do nothing but sleep (P13/teacher mainstream education)

In some instances, participants' negative perceptions of the capabilities of people with ID led them to express pity (kasihan). 
I would feel pity (kasihan) (for Gilang, severe ID)... feel pity because I can imagine his future, where he can't be independent and very dependent on his mother (P05/teacher mainstream education)

Participants in all three professional groups anticipated that they would need to make extra efforts to provide services for people with ID as they are perceived as less capable.

If I had a client like Gilang, I would feel 'oh God, it will take a lot of energy to work with... a lot of things will need to be done for him... not to mention the struggle to work with him in person because he only speaks a few words and he cannot read or write'... (P01/educational psychologist)

Despite expecting that they would need to make extra efforts, all participants expressed their eagerness to accommodate people with ID who attended their services. In addition, a participant also mentioned that their feeling of pity comes in parallel with eagerness to help.

I would give him support, to bring some confidence to him, to make him feel accepted. Because of his limitation, people in the community tend to exclude him... I would support him and guide him carefully... (P10/religious leader-Islam)

It feels like I love and take pity on them but at the same time I must teach and help them... it is sometimes... complicated, a combination of affections, the obligation to provide them with education, and pity (P06/teacher special education)

\section{Theme four: Attitudes towards the inclusion of people with ID}

This theme is comprised of eight sub-themes represent factors influencing attitudes towards the inclusion of people with ID, as seen in Figure 3. 


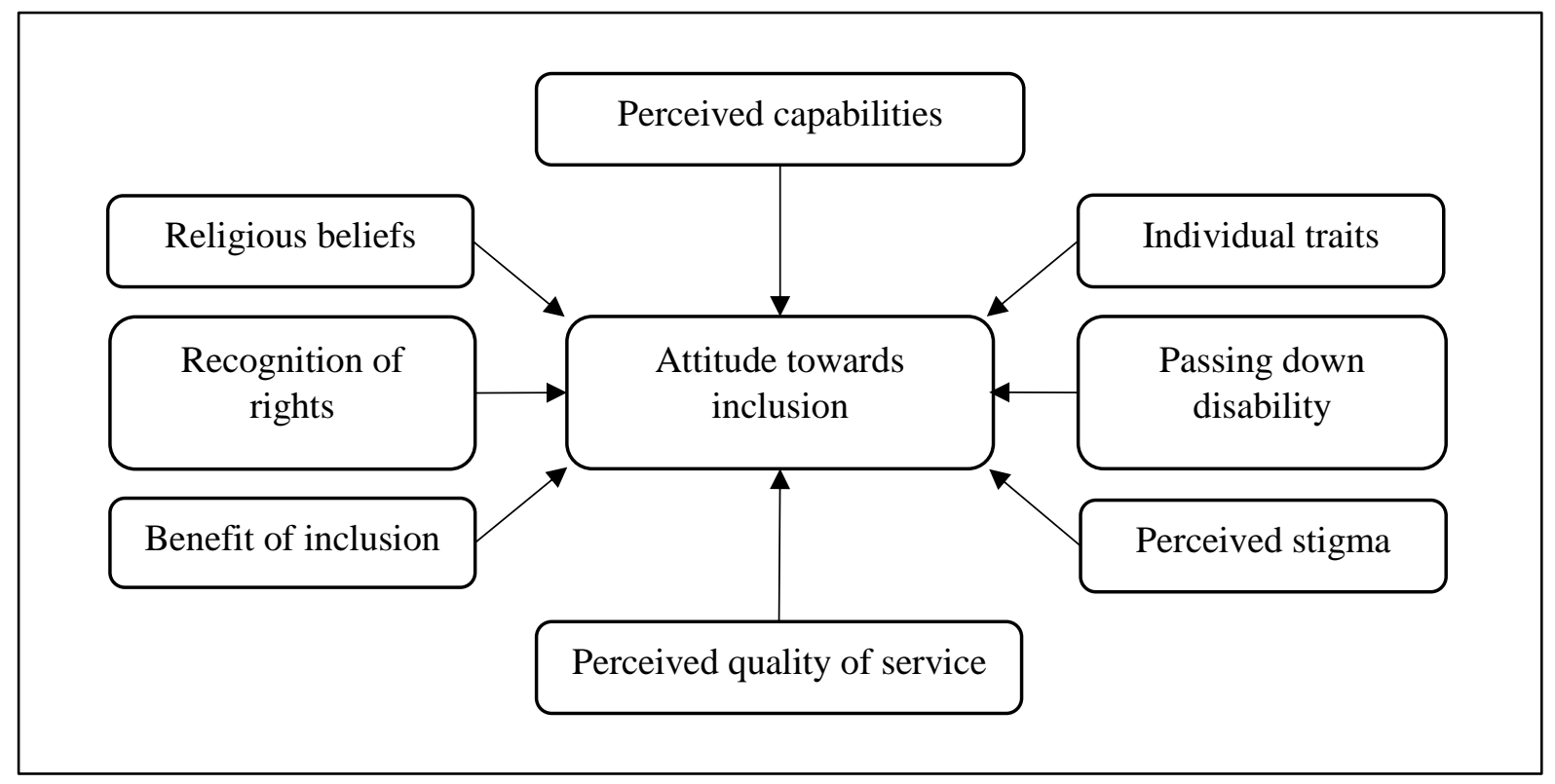

Figure 3. Attitudes towards the inclusion of people with ID

Participants were inclined to a positive attitude towards the inclusion of people with ID in all five domains explored in this study (education, employment, marriage and parenthood, participation in community activities, and living arrangements). However, participants were more favorable towards the inclusion of people with mild ID.

People like Rudy (mild ID) should live at home with his family if he is single. If he is married, then it is okay for him to live separately... Q: what about Gilang (severe ID)? A: to stay with his family (P05/teacher mainstream education)

They noted the lack of good quality services for people with ID in Indonesia, and the gulf in educational quality between public and private schools, with the latter perceived to be of higher quality yet inaccessible for people of low economic status.

The quality of inclusive education in Indonesia, especially those run by the government, is poor... if the parent is wealthy, then they can send him to a private, inclusive school, but if the parent is poor... then I prefer to recommend him to go to a special school (P01/educational psychologist) 
if we put him (Gilang, severe ID) in a school, even in a special school, the teachers will not be able to attend the students in a one on one basis... They don't have sufficient human resources... I prefer home-schooling (for Gilang, severe ID) (P11/religious leader-Protestant)

Participants who recognised the benefit of inclusion and the rights of people with ID are more likely to give an inclusive recommendation, including for participation in an election.

... an inclusive school is the most appropriate... it is to provide him with a chance to socialise with more able people and to improve his communication skills (P05/mainstream education teacher)

He has the right. In a general election, everyone has a voice, and it needs to be respected (P02/medical doctor)

However, some participants were more hesitant to endorse marriage and/or parenthood of people with ID despite recognising marriage and parenthood as human rights.

It is human rights... but if you ask my perspective on this issue, I think they should not (marry)... Based on my experience... it will end with disaster (P06/special education teacher).

Hesitation to endorse marriage and/or parenthood among participants is related to concern about the possibility of passing down the disability. A participant went as far as recommending sterilisation as a countermeasure.

I am worried he might pass his condition to his children. If he is married, he should go for sterilisation, to ensure he will not have a child (P15/educational psychologist)

Religious beliefs were found to influence attitudes towards marriage and/or parenthood among participants from the religious leader group. 
In the Book of Genesis, it is written 'Be fruitful and increase in number; fill the earth and subdue it'. Having a child is a mandate for married people, and it is an expectation from society and religion... (P11/religious leader-protestant)

Participants identified stigma and personal traits as a barrier to inclusion especially in educational settings and participation in community activities.

There will always be people who perceive individuals with disabilities using derogatory views and remarks, such as 'give it up', 'you don't understand', 'do not even try to get involved (in the activity) ... moreover, if the person himself does not like being in a crowd, then he will have a hard time to participate (in community activities)' (P01/educational psychologist)

Stigma was reported to be internalised by families, leading to limited participation in community activities.

Some families are ashamed to have children like him. So, they never bring such a child to wedding ceremonies. There are cases of parents hiding their child (P07/special education teacher)

Discrimination such as bullying, gossip, and name calling was reported to be present in the community, resulting in people with ID being marginalised and excluded. Therefore, endorse participants to advise people with ID to less inclusive options.

But if his (Rudy, mild ID) parents thinks that it is impossible for the child to go to school because they are worried about bullying. I often hear about children with disabilities being bullied... It is hard for me to say this, but it is the truth. Then the second option is homeschooling (P11/religious leader-protestant)

The younger members of the society were said to more likely discriminate against people with ID. 
We may find children do such thing to them... Adults, I think they would not mind... they (the children) don't have an ill intention; they just want to have fun, to make fun of people with disabilities (P17/ religious leader-Hindu)

\section{Theme five: Religion and ID}

As discussed in the section about perceived causes of ID, religious leaders explained ID as an ordeal imposed by God or a punishment for past sins (karma, hereditary sin). It is important to note that participants saw these concepts as not necessarily stigmatising of people with ID. The Hindu religious leader emphasised that karma is a personal process deemed important to purify the soul (atman) and that the person receiving his/her karma should not be shunned as the punishment has been settled prior to his/her rebirth.

Because, from our perspective, it had been settled, because the process (of karma) is very personal. What had happened, has been settled... Now the person is born a new (P17/religious leader-Hindu)

The Protestant and the Catholic religious leaders emphasised that the concept of hereditary sin is no longer recognised in the religion but the Protestant religious leader noted that it is still endorsed by priests of the previous generation, while younger priests tend to hold more positive perspectives of disability.

... I remember that some priests have a funny perspective about disability. They relate disability with parents' sins... there is a concept of hereditary sin, although, in Christianity, the concept no longer exists (P11/ religious leader-Protestant)

Persons with disabilities are expected to be patient and adhere to the teachings of each religion as included in its holy books. In Islam, although disability is considered an imperfection, all humans are perceived to have some form of imperfection. Therefore, there is 
no reason to disregard people with disabilities on religious grounds. Treating people with disabilities with respect and honour is an Islamic teaching.

The Prophet had an acquaintance who also had a disability... he was honoured by the prophet; he was cared for by the Prophet... (P09/religious leader-Islam)

Similar beliefs and teachings were also expressed in an interview with the Protestant religious leader, who cited a parable from the Bible about a person with a disability who was received at a banquet.

King Saul had a son named Mephibosheth. He was born with a disability... after King Saul died, King David welcomed Mephibosheth to dine at the same table as him (P11/religious leader-Protestant)

All participants from the religious leader group said that they would welcome people with ID at their service. One participant thought that the presence of people with ID at religious sermons would motivate the public to attend more frequently.

I would feel grateful... with his condition, to attend a religious sermon... he would encourage other members to come and study religion (P09/religious leader-Muslim)

There are various activities they (people with ID) could be involved in the Vihara (Buddhist monastery). They could go to the Sunday school which we have here (the Vihara) (P16/religious leader-Buddhist)

The Protestant religious leader suggested that people with ID could well play a (simple) role in religious activities, for example as ushers and welcoming worshippers.

There is a role we call 'usher'. They are the receptionists. We could ask Rudy (mild ID) and Gilang (severe ID) to be the receptionists... we can ask Rudy to say something like 'Happy Sunday' or 'Welcome to the church' (P11/religious leader-Protestant) 


\section{Theme six: Family-centric support}

Most participants mentioned family as the central support for people with ID across domains of inclusion explored in this study, especially for living arrangement and lifelong support.

Gilang (severe ID) can’t live independently... he needs other's support and companionship. Q: Whom do you mean by other? A: Well, if his parents are no longer here, then his brother or sister should support him (P10/religious leader-Islam)

Following this perspective, participants expressed the idea of marriage as a supporting system to complement and/or substitute the role of parents and sibling.

I think having a family is not only about Rudy himself. When he is married, there will be others to help him, his wife, and his parents (P05/teacher mainstream education)

I think it is important to have a child. And it will also be beneficial to have the children to care for Rudy in his old age (P09/religious leader-Islam)

The Buddhist religious leader mentioned the expectation towards the family of caring for their members with a disability as part of religious teaching.

...we have a sentence from the holy book, if I may cite, there is the responsibility of parents towards their children, and there is the responsibility of children towards their parents. For example, is to care for children when they are ill... In the future... they could never be left alone, and therefore the parents should take the role (P16/religious leader-Buddhist)

One participant perceived attempts to send people with ID to special institutions or arranging their marriage as an attempt by families trying to relinquish their responsibilities.

I don't recommend them to live there (special institution), because sending them to an institution may... be interpreted as removal of responsibility (from the family) (P04/medical doctor) 


\section{Theme seven: Challenges faced by people with ID in a wider context}

Poverty, as well as a lack of awareness and support from the government, were identified as the main challenges faced by people with ID in Indonesia. Both are associated with limited accessibility, availability of services, and opportunities for inclusion. In addition, adverse socioeconomic conditions mean that the basic needs of persons with ID and their families are often unmet.

If they come from a poor family, life may be hard for them, because their parents should balance their focus between earning money to meet daily needs and look after their children, which takes a lot of their time (P04/general practitioner)

Participants commented on the government's lack of interest in or prioritisation of people with disabilities, as well as acknowledging that a prevailing view suggests that people with ID are burdens to society. One participant cited a comment from a member of parliament, expressing this perspective.

I heard a comment from one Member of Parliament regarding people with disabilities. He said, 'we can't afford to care for the handicapped while we still have normal people being left without care'. It is an example of the unsupportive environment faced by people with disabilities (P15/educational psychologist)

\section{Discussion}

The findings suggest that apparent or perceived deficits in adaptive abilities play an essential role in both attitudes towards people with ID and their inclusion in society. Therefore, participants showed more favourable attitudes towards people with mild ID and their inclusion compared to those with severe ID, which reflects the attitudes of the general public (Morin, Rivard, Crocker, Boursier, \& Caron, 2013). In line with their attitudes, participants were more likely to advocate inclusive options for people with mild ID and more restrictive ones for 
people with severe ID in their advice. The finding suggests that the nature and the severity of the disability were important drivers behind less favourable individual and public responses to inclusive practices (Avramidis \& Norwich, 2002). It is also critical to note that a condition that may influence participants' attitudes towards inclusion is the availability of good quality services (Avramidis \& Norwich, 2002). In general, participants perceived that the services currently available for people with ID in Indonesia are underdeveloped and limited.

Studies from neighbouring countries (Malaysia and Singapore), suggests similar findings of positive attitudes among professionals. The studies found that teachers hold positive attitudes towards the inclusion of people with disability people (Ali, Mustapha, \& Jelas, 2006; C. Clarke \& Nomanbhoy, 1998; Lian et al., 2008). A study from Indonesia also found that mainstream teachers are eager to use sign language for students with severe ID (Sheehy \& Budiyanto, 2014) which again confirmed present findings. However, it is crucial to carefully interpret the findings as this study use hypothetical cases (C. Clarke \& Nomanbhoy, 1998) when discussing people with ID and their inclusion. One factor that may influence participants' attitudes in the present study is the extent of exposure. Participants in this study, aside from the three special education teachers, have not had much exposure to people with ID. Stakeholders with less exposure to people with ID are known to have more positive attitudes towards inclusion (Avramidis \& Norwich, 2002). In their recommendation regarding community participation and employment, participants seem to have little consideration for social factors such as public attitudes and accessibility to employment that hamper inclusion. It is reported that people with disability in Indonesia have low access to employment (Prasetyo, 2014), and high levels of stigma towards people with ID present in the society (Komardjaja, 2005). Thus, participant's recommendation may be seen as representing an idealistic point of view, regardless actual condition. Nevertheless, the positive attitudes found in this study should be 
regarded as a strength and suggests that opportunities to promote and endorse the inclusion of people with ID in the society.

Hofstede (2001) defines culture as "the collective programming of the mind that distinguishes the members of one group or category of people from another" (p. 9), which includes beliefs, attitudes, skills and values. In this study, three factors that are embedded within the cultural context of Indonesia were found to underpin attitudes towards people with ID in Indonesia: family-centric support, interpretation of religious beliefs, and interpretation of 'pity', each discussed in turn below.

The family was cited as the primary source of support for people with ID, which may relate to the limited and underdeveloped services (e.g. daycare, professional provision) discussed earlier. An alternative explanation for this family-centric support may lie with Indonesian cultural values. Indonesian is a collectivist society and loyalty to family is paramount (Hofstede, 2001). These values are reflected, for example, in the Indonesian annual custom of 'homecoming' (Mudik) to celebrate the end of Ramadhan (the Muslim fasting month), which has long become an inclusive custom regardless of ethnicity and religion (Yulianto, 2011). During Mudik, millions of people travel from urban areas, where they work and make a living, to rural areas where their families live. Given their loyalty to family, children are expected to care for parents in their old days, as sending them to a care home would be seen as irresponsible or even treason (durhaka). In a collectivist society, the family is seen as the source of protection against the hardship of life (Hofstede, 2001). Therefore, the family is expected to hold responsibility for family members with a disability. It is important to note that due to the family is seen as the primary source of support while professional support is lacking, it is essential to consider families' viewpoints regarding care for their members with ID. Several studies have found associations between caring for a family member with ID with lower quality of life 
(Brown, MacAdam-Crisp, Wang, \& Iarocci, 2006), depression (Olsson \& Hwang, 2001), stigma, and social restrictions (Ngo, Shin, Nhan, \& Yang, 2012) in caretaking.

Causal explanations of ID which are based on the belief of God's punishment, ordeals and past sin emerged during the interview with the religious leaders. Such beliefs are known to be related to negative attitudes (Carter, 2009; Hubert, 2006; Moreira, 2011; Scior \& Furnham, 2016). However, it is interesting that the religious leaders' attitudes were more inclined towards the positive as it was reflected in the overall finding of this study. This was possible because the religious leaders in this study were interpreting those beliefs in a more positive tone, which allows them to express positive attitudes despite holding such beliefs. Interpretation (or reinterpretation) of religious beliefs and teachings is a privilege held by religious leaders, which could be seen as an opportunity to endorse positive attitudes among the followers.

The majority of participants express pity (kasihan) as their emotional response towards people with disability. Pity was expressed as the basis of their eagerness to help, including when providing their services as professionals. While pity is generally perceived as a negative and unwanted response within the context of disability, it is arguably considered as positive and expected response in Indonesian context and its neighbouring countries such as Cambodia (Moreira, 2011). The word 'kasihan', which commonly used as translation of 'pity', shares similar meaning to 'belas kasih' which can be translated to 'mercy' or 'compassion'; it derived from a homonym Indonesian word of 'kasih' which means 'love' or 'to give' (Alwi, 2007). Therefore the word 'kasihan' is hardly considered to be derogatory in its literal meaning. In the Indonesian context, it is almost obligatory to feel 'kasihan' as a response to people perceived to be in needs or facing hardship, while not feeling 'kasihan' to such people may attribute to lack of compassion or heartless. Therefore, participants response related to pity in the present finding should not be prematurely judged as a negative response, and consideration towards the cultural context of 'pity' should be endorsed in the effort to explore attitude across 
cultural contexts. In parallel, the reaction of people with ID towards 'pity' and their expectation of social response should also be further explored and accounted for.

Participants identified stigma as the barrier of inclusion. Stereotypes, derogatory terms, bullying and the idea that sterilising people with ID is acceptable were mentioned in the interviews; similar findings were found in studies conducted in a Cambodian context (Carter, 2009; Moreira, 2011). Bullying was reported by participants as happening in educational settings and in the wider community. Bullying in educational settings suggests that more work is needed to target disablist attitudes among children and young people, as well as at community level. Stigma was associated with lack of awareness and knowledge, as well as the perspective of disability among community members. The perspective that people with disabilities are a burden on society were reported to be held by politicians in the country, but there is no other evidence to confirm or refute what may be anecdotal conjecture. The perspective that people with disabilities are a burden to society, as reported in this study, must be critically challenged if positive attitudinal changes are to take hold and affect the availability and quality of public services for people with ID in Indonesia. Given that stigma was reported to be present, it is critical to explore the experience and everyday life of people with ID further, as well as the extent to which they are affected by stigma.

\section{Strengths and limitations of the study}

This study is the first to explore the attitudes of professionals towards people with ID in an Indonesian context. Semi-structured interviews were conducted in this study, thereby offering the flexibility to explore key points and perspectives as they arise. Interviews were conducted by a single interviewer (RTH), which provided a standardised process for carrying out semistructured interviews. RTH is a native Indonesian clinical psychologist who has experience working with people with ID in Indonesia. Five domains of inclusion were covered in this 
study, providing broad perspectives on the inclusion of people with ID in the Indonesian context.

The number of participants in the study was small, and participants were self-selected. Therefore, participants' perspectives may not represent the wider community of professionals working with ID in Indonesia. Convenience sampling, including the use of authors' work and personal contacts and snowballing utilised in this study, accounted for further sampling bias and issue on representativeness. However, the authors took advantage of the flexibility inherent in convenience sampling to gain a wider perspective, seen for example in the recruitment of religious leaders from five different religions. As the participants in this study are heterogeneous, differences in their beliefs, values, and knowledge may influence their attitudes towards people with ID and inclusion, which was most evident among religious leaders whose attitudes were influenced by their religious beliefs of piety and unconditional acceptance. Participants were recruited in selected urban areas due to resources available for this study. Therefore, this study may not reflect a more traditional community in rural areas, in which religion may play a greater role. Information on participants' prior contact with people with ID was based on self-reporting, which may not be accurate for participants who are unfamiliar with the characteristics of ID.

Thematic analysis was utilised in this study as it provides a flexible approach which can be modified to accommodate the need of many studies (Nowell, Norris, White, \& Moules, 2017), including those with small data sets and heterogeneous samples (V. Clarke \& Braun, 2016) such as the present study; while also providing detailed and rich data (Nowell et al., 2017). However, the flexibility of thematic analysis offered as its main advantage can also be a disadvantage, as it may lead to a lack of coherence in theme development (Nowell et al., 2017). 


\section{Conclusion}

This study provides information on attitudes towards people with ID and their inclusion in Indonesia, as reported by key professional group participants. Overall, the findings are encouraging. Cultural factors shaped attitudes towards people with ID in this setting, especially in the absence of focused efforts that may influence such attitudes and promote change. There is an urgent need for greater efforts to reduce stigma and promote inclusion of people with ID in general Indonesian society.

\section{Declaration of Conflicting Interest}

The author(s) declared no potential conflicts of interest with respect to the research, authorship, and/or publication of this article.

\section{Funding}

This study was funded by Indonesia Endowment Fund for Education (Lembaga Pengelola Dana Pendidikan). Registration number: 20150922304211.

\section{Acknowledgements}

We thank all the collaborating institutions for their support with participant recruitment. We are also grateful to Ms. Ria Dwi Agustina for reviewing the initial coding structure of this study. 


\section{Reference}

Ali, M. M., Mustapha, R., \& Jelas, Z. M. (2006). An Empirical Study on Teachers' Perceptions towards Inclusive Education in Malaysia. International journal of special education, $21(3), 36-44$.

Alwi, H. (2007). Kamus besar bahasa Indonesia (Indonesian language big dictionary). In: Jakarta: Balai Pustaka.

American Psychiatric Association. (2013). Diagnostic and statistical manual of mental disorders (5th ed.). Washington, DC: Author.

Arifin, E. N., Ananta, A., Wilujeng Wahyu Utami, D. R., Budi Handayani, N., \& Pramono, A. (2015). Quantifying Indonesia's Ethnic Diversity. Asian Population Studies, 11(3), 233256. doi:10.1080/17441730.2015.1090692

Avramidis, E., \& Norwich, B. (2002). Teachers' attitudes towards integration / inclusion: a review of the literature. European journal of special needs education, 17(2), 129-147.

Berry, J., \& Dalai, A. (1996). Disability attitudes, beliefs and behaviours: preliminary report on an international project in community based rehabilitation. Unpublished Manuscript. ICACBR, Queen's University. Kingston, Canada.

Braun, V., \& Clarke, V. (2006). Using thematic analysis in psychology. Qualitative Research in Psychology, 3(2), 77-101.

Brown, R., MacAdam-Crisp, J., Wang, M., \& Iarocci, G. (2006). Family Quality of Life When There Is a Child With a Developmental Disability. Journal of Policy and Practice in Intellectual Disabilities, 3(4), 238-245.

Budiyono. (2014). Hubungan negara dan agama dalam negara Pancasila (the relationship of state and religion in a Pancasila state). Fiat Justisia Jurnal Ilmu Hukum, 8(3), 410-423.

Carter, J. (2009). Preparing for the journey: A cooperative approach to service provision for children with intellectual disabilities in Cambodia. Phnom Penh: Hagar. 
Clarke, C., \& Nomanbhoy, D. M. (1998). Attitudes of Singapore pre-school centre personnel on integrating children with disabilities. Early Child Development and Care, 144, 119128.

Clarke, V., \& Braun, V. (2016). Thematic analysis. The Journal of Positive Psychology, 12(3), 297-298. doi:10.1080/17439760.2016.1262613

Ditchman, N., Werner, S., Kosyluk, K., Jones, N., Elg, B., \& Corrigan, P. W. (2013). Stigma and intellectual disability: Potential application of mental illness research. Rehabilitation Psychology, 58(2), 206.

Edwards, N. J. (2014). Disability Rights in Indonesia? Problems with Ratification of the United Nations Convention on the Rights of Persons with Disabilities. Australian Journal of Asian Law, 15(1), 1-15.

Francis, J., Francis, J. J., Johnston, M., Robertson, C., Glidewell, L., Entwistle, V., . . . Grimshaw, J. (2010). What is an adequate sample size? Operationalising data saturation for theory-based interview studies. Psychology \& health, 25(10), 1229-1245.

Hofstede, G. (2001). Culture's consequences : comparing values, behaviors, institutions, and organizations across nations (2nd ed.). London: Sage Publication, Ltd.

Hubert, J. (2006). Family carers' views of services for people with learning disabilities from Black and minority ethnic groups: a qualitative study of 30 families in a south London borough. Disability \& Society, 21(3), 259-272.

Indonesia Ministry of Health. (2013). Riset kesehatan dasar (basic health research). Jakarta: Author.

Indonesia Statistics. (2015). Penduduk Indonesia: Hasil survei penduduk antar sensus 2015 (Population of Indonesia: Result of the 2015 intercensal population survey). Retrieved from Jakarta: https://www.bps.go.id 
Irwanto; Kasim, E. R., Fransiska, A., Lusli, M., \& Okta, S. (2010). Analisis situasi penyandang disabilitas di Indonesia: Sebuah desk review (analysis of the situation of people with disability in Indonesia: a desk review). Jakarta: Pusat Kajian Disabilitas Fakultas Ilmu Sosial dan Politik Universitas Indonesia.

Jones, N. (2005). Rediscovering Pancasila: Religion in Indonesia's public square. The Brandywine Review of Faith \& International Affairs, 3(1), 23-30.

Komardjaja, I. (2005). The place of people with intellectual disabilities in Bandung, Indonesia. Health \& place, 11(2), 117-120.

Lian, W. B., Ying, S. H., Tean, S. C., Lin, D. C., Lian, Y. C., \& Yun, H. L. (2008). Pre-school teachers' knowledge, attitudes and practices on childhood developmental and behavioural disorders in Singapore. Journal of Paediatrics \& Child Health, 44(4), 187194.

Maulik, P., Mascarenhas, M., Mathers, C., Dua, T., \& Saxena, S. (2011). Prevalence of intellectual disability: A meta-analysis of population-based studies. Research in Developmental Disabilities, 32(2), 419-436.

Moreira, R. A. (2011). Intellectual Disability in Rural Cambodia: Cultural perceptions \& families' challenges. Retrieved from http://www.rencontres-shscambodge.ird.fr/content/download/50054/383029/version/1/file/Research+Intellectual $\underline{+ \text { Disability }+ \text { in }+ \text { Rural+Cambodia- }}$

\section{Cultural+Perception $+\% 26+$ Families $\% 27+$ Challenges.pdf}

Morin, D., Crocker, A. G., Beaulieu-Bergeron, R., \& Caron, J. (2013). Validation of the attitudes toward intellectual disability: ATTID questionnaire. J Intellect Disabil Res, 57(3), 268-278. doi:10.1111/j.1365-2788.2012.01559.x 
Morin, D., Rivard, M., Crocker, A. G., Boursier, C. P., \& Caron, J. (2013). Public attitudes towards intellectual disability: a multidimensional perspective. Journal of Intellectual Disability Research, 57(3), 279-292.

Mujaddid. (2014). Kesehatan anak dengan disabilitas (the health of children with disabilities). Buletin Jendela: Data dan informasi kesehatan, situasi penyandang disabilitas.

Ngo, H., Shin, J. Y., Nhan, N. V., \& Yang, L. H. (2012). Stigma and restriction on the social life of families of children with intellectual disabilities in Vietnam. Singapore Medical Journal, 53(7), 451-457.

Nowell, L. S., Norris, J. M., White, D. E., \& Moules, N. J. (2017). Thematic Analysis:Striving to Meet the Trustworthiness Criteria. International Journal of Qualitative Methods, 16(1), 1609406917733847. doi:10.1177/1609406917733847

Olsson, M. B., \& Hwang, C. (2001). Depression in mothers and fathers of children with intellectual disability. Journal of intellectual disability research, 45(6), 535-543.

Prasetyo, F. (2014). Disabilitas dan isu kesehatan: Antara evolusi konsep, hak asasi, kompleksitas masalah dan tantangan (disabilities and health issues: between the concept evolution, basic rights, problem complexities and challenges). . Buletin Jendela: Data dan informasi kesehatan, situasi penyandang disabilitas.

Riana, A. (2014). Program rehabilitasi sosial penyandang disabilitas dan pergeseran paradigma penanganan penyandang disabilitas (social rehabilitation program of people with disabilities and paradigm shift of the management of people with disabilities). Buletin Jendela: Data dan informasi kesehatan, situasi penyandang disabilitas.

Scior, K., \& Furnham, A. (2016). Causal beliefs about intellectual disability and schizophrenia and their relationship with awareness of the condition and social distance. Psychiatry research, 243, 100-108. 
Scior, K., Hamid, A., Hastings, R., Werner, S., Belton, C., Adebisi, L., . . Kett, M. (2015). Intellectual Disabilities: Raising Awareness and Combating Stigma- a Global Review. Retrieved from London: https://www.ucl.ac.uk/ciddr/publications

Sheehy, K., \& Budiyanto. (2014). Teachers' attitudes to signing for children with severe learning disabilities in Indonesia. International Journal of Inclusive Education, 18(11), 1143-1161. doi:10.1080/13603116.2013.879216

Tregaskis, C. (2000). Interviewing non-disabled people about their disability-related attitudes: Seeking methodologies.

Werner, S., \& Scior, K. (2016). Interventions aimed at tackling intellectual disability stigma: What works and what still needs to be done. In K. Scior \& S. Werner (Eds.), Stigma and intellectual disability: Stepping out from the margins (pp. 129-148). Basingstoke: Palgrave Macmillan.

Woodward, M. (2011). Yogyakarta: Religion, Culture and Nationality. In Java, Indonesia and Islam (pp. 1-67): Springer.

World Health Organization and the World Bank. (2011). World Report on Disability. Retrieved from http://www.who.int/disabilities/world_report/2011/en/

Yazbeck, M., McVilly, K., \& Parmenter, T. R. (2004). Attitudes toward people with intellectual disabilities: An Australian perspective. Journal of Disability Policy Studies, 15(2), $97-$ 111.

Yulianto, V. I. (2011). Is the Past Another Country? A Case Study of Rural-Urban Affinity on Mudik Lebaran in Central Java. Journal of Indonesian Social Sciences \& Humanities, 4. 


\section{Appendix A: Interview schedule}

\section{English}

\section{Introduction}

1) Overview of role and profession: Ask the respondent to explain a bit about his/her self, their profession and their role.

2) Prior contact: Have you met people with a condition similar condition to that of Rudy/Gilang? on what occasion?

3) Knowledge about conditions and terms: What do you think happen to Rudy/Gilang? Prompts:

Do you know any terms that are used to describe people like Rudy/Gilang?

Are you familiar with the terms intellectual disability? mental retardation? (one at a time)

\section{Attitudes towards people with ID}

4) Causal beliefs: What do you think caused Rudy's/Gilang's condition?

5) Future life: What kind of future will Rudy/Gilang have?

6) Attitude as professional: How do you feel having people like Rudy/Gilang as your patient/ student/ congregation member? What would you do for them?

\section{Attitudes towards inclusion of people with ID}

7) Education: What kind of education is suitable for people like Rudy/Gilang?

Prompts:

$>$ Options: mainstream school, special school, inclusive school, home-school?

8) Living arrangements: What kind of living arrangements are suitable for people like Rudy/Gilang?

Prompts:

Options: own house, family house, boarding special institution 
9) Employment: Do you think Rudy is able to be employed?

Prompt:

What kind of job is suitable for Rudy?

10) Marriage and parenthood: Do you think Rudy is able to marry? Do you think he should have his own child? Why?

11) Participation in community activities: Do you think Rudy/Gilang should be involved in community activities?

Prompts:

$>$ Public festivities, weekly prayers, elections

\section{Indonesian}

\section{Pembuka}

1) Latar belakang peran dan profesi: Tanyakan kepada responden untuk menjelaskan sedikit mengenai dirinya, serta profesi dan perannya.

2) Kontak sebelumnya: Apakah anda pernah bertemu dengan orang yang memiliki kondisi seperti Rudy/gilang? Dalam situasi apa?

3) Pengetahuan mengenai kondisi dan istilah: Menurut anda apa yang terjadi pada Rudy/Gilang?

$>$ Istilah apa yang biasa digunakan untuk merujuk orang-orang seperti Rudy/gilang?

Apakah anda familiar dengan istilah disabilitas intelektual? Retardasi mental? (satu per satu) 


\section{Sikap terhadap orang dengan DI}

4) Penyebab: Menurut anda apa yang menyebabkan Rudi/Gilang mengalami kondisi tersebut?

5) Masa depan: Masa depan seperti apa yang akan dimiliki oleh Gilang/Rudi?

6) Sikap sebagai professional: Apa yang anda rasakan saat mendapatkan pasien/murid/jamaat_seperti Rudy dan Gilang? Apa yang akan anda lakukan untuk mereka?

\section{Sikap terhadap inklusi pada DI}

7) Pendidikan: Pendidikan seperti apa yang tepat untuk orang seperti Rudy/Gilang?

Prompt:

Pilihan: Sekolah regular, sekolah luar biasa, sekolah inklusi, home-schooling

8) Tempat tinggal: Tempat tinggal seperti apa yang tepat untuk orang seperti Rudy/Gilang?

Prompt:

Pilihan: Rumah sendiri, rumah keluarga, institusi khusus dengan bentuk asrama

9) Pekerjaan: Apakah Rudy dapat memiliki pekerjaan?

Prompt:

$>$ Pekerjaan seperti apa yang tepat untuk Rudy?

10) Pernikahan dan keturunan: Apakah Rudy dapat menikah? Apakah sebaiknya dia memiliki keturunan? Kenapa?

11) Partisipasi dalam kegiatan masyarakat: Apakah Rudy/Gilang sebaiknya terlibat dalam kegiatan masyarakat?

Prompt:

Perayaan hari besar, ibadah mingguan, pemilu/pilkada 


\section{Appendix B: Vignettes}

\section{English}

\section{Vignette 1}

Rudy is 22 and lives at home with his family. As a child, he struggled to follow lessons taught at school and dropped out after being held back in the same grade twice. Rudy is capable of taking care his personal daily needs such as maintaining self-hygiene (bathing, changing clothes, toilets) and feeding, but sometimes his parent needs to remind him. Rudy can engage in conversation with other people. However, he has difficulties in understanding abstract concepts. He owns a mobile phone and is able to use it. He can read and write at a basic level but cannot read a newspaper, or use money correctly to pay for things.

\section{Vignette 2}

Gilang is 19 years old and lives at home with his family. He has difficulty communicating his needs as he can only speak a few words and cannot read or write. His mother supports him in most of his needs, which include bathing him and dressing him. He can feed himself, but he cannot be left on his own, and he cannot go outside and his own as he is unaware of how to keep himself safe.

\section{Indonesian}

\section{Kasus 1}

Rudy berusia 22 tahun. Saat ini Ia tinggal di rumah bersama keluarganya. Semasa sekolah dasar ia mengalami kesulitan untuk mengikuti pelajaran. Ia pernah tinggal kelas sebanyak dua kali, sebelum akhirnya putus sekolah. Rudy mandiri dalam menjaga kesehatan dan merawat diri (contoh: mandi, berpakaian, makan), walaupun kadang perlu diingatkan. Rudy dapat diajak 
berbicara, tetapi ia kesulitan untuk membicarakan hal-hal yang bersifat abstrak dan terlalu rumit. Ia tahu bagaimana cara menggunakan telepon. Rudy dapat membaca dan menulis dalam tingkatan sederhana, tetapi ia tidak dapat membaca koran atau menggunakan uang untuk membayar dengan jumlah yang benar.

\section{Kasus 2}

Gilang berusia 19 tahun, Saat ini Ia tinggal di rumah bersama keluarganya. Gilang sulit untuk memberitahu orang lain tentang keinginannya, karena ia hanya dapat berbicara beberapa patah kata saja. Gilang tidak dapat membaca ataupun menulis. Ibunya harus selalu membantu Gilang untuk memenuhi kebutuhannya sehari-hari, seperti mandi dan berpakaian. Gilang dapat menyuap makanannya sendiri, tetapi ia tidak dapat ditinggal seorang diri. Gilang tidak dapat pergi ke luar rumah sendiri, karena ia tidak tahu bagaimana cara menjaga keamanan dirinya di luar rumah. 